\title{
KOMUNIKASI MULTILINGUAL PADA KOMUNITAS SANTRI PONDOK PESANTREN MAHASISWA DARUSSALAM DI KARTASURA
}

\author{
Aulia Normalita $^{1}$, Wahyu Oktavia ${ }^{1}$ \\ Institut Agama Islam Negeri Surakarta \\ Email: aulianormalita@gmail.com
}

\begin{abstract}
Abstrak
Penelitian ini bertujuan untuk menemukan penggunaan multilingual yang ada pada komunitas santri di pondok pesantren Mahasiswa Darussalam di Kartasura yang ditinjau dari kajian sosiolinguistik. Penelitian ini difokuskan pada tuturan bahasa sehari-hari dari keanekaragaman bahasa dan keanekaragaman budaya oleh santri di sebuah pondok pesantren Mahasiswa Darussalam Kartasura yang melibatkan unsur alih kode dan campur kode. Metode yang digunakan dalam penelitian ini adalah deskripsi kualitatif dengan mendeskripsikan setiap tuturan yang dituturkan oleh setiap santri. Teknik dalam analisis data menggunakan teknik simak dan rekam dengan observasi dan wawancara yang diambil dari peristiwa-peristiwa tutur sehari-hari yang terjadi di pondok pesantren Mahasiswa Darussalam Kartasura. Hasil penelitian menunjukkan adanya wujud bahasa multilingual dan faktor-faktor yang menjadi penyebab adanya bahasa multilingual.
\end{abstract}

Kata kunci: multilingual, alih kode, campur kode, santri

\begin{abstract}
This study aim to find out the use of multilingual language in darussalam boarding school Kartasura in the term of sociolinguistic. This study focus on the daily conversation, variety of language and variety of the culture by the students of Darussalam islamic boarding school that involve kode swiching and kode mixing. This study use the decriptive qualitative method by describe every utterence that use by all of the students of Darussalam islamic boarding school. The Technique of analysis data use observation and interview that conducted in the daily life that occure in the Darussalam islamic boarding school. The result of the study show there is multilingual and the factor cause of multilanage language.
\end{abstract}

Keywords: multilingual, kode swiching, kode mixing, santri

\section{PENDAHULUAN}

Pada masyarakat tertentu ada yang menggunakan bahasa khas mereka sendiri, namun adapula dalam suatu masyarakat yang menggunakan banyak bahasa dari beberapa daerah di dalam satu tempat. Artinya meskipun mereka tinggal dalam satu lingkup daerah, bahasa yang mereka gunakan bermacam-macam. Hymes (1973) mengatakan bahwa masyarakat dan bahasa tidak bisa dipisahkan, bahasa untuk masyarakat dan masyarakat untuk bahasa. Jadi keduanya sama-sama memiliki keterkaitan yang tidak dapat dipisahkan. Bahasa adalah sebagai alat komunikasi yang selalu mengalami reproduksi perkembangan, perubahan atau pergeseran atau pemusnahan. Reproduksi pergeseran dan musnahnya sebuah bahasa dimungkinkan terjadi akibat dari adanya faktor kontak komunikasi antar masyarakat yang berdwibahasa (bilingualism) atau bermulti bahasa (multilingualism) oleh penutur bahasa yang berkembang di masyarakat.

Muhammad (2016) penutur sebagai masyarakat bahasa di berbagai wilayah di Indonesia secara empiris mereka pada umumnya di dalam berkomunikasi sehari-hari mereka menggunakan 
lebih dari satu bahasa. Istilah kedwibahasaan (bilingualism) digunakan untuk kemampuan menggunakan atau kebiasaan dua bahasa atau kegandaan dua bahasa (multilingualism). Fishman (dalam Chaer, 2010:23) mengatakan bahwa dalam mengkaji masyarakat dwibahasa atau multibahasa hendaknya diperhatikan dengan ada tidaknya diglosia. Fishman juga mengatakan bahwa diglosia tidak hanya terdapat pada masyarakat yang mengenal satu bahasa dengan dua ragam bahasa sematamata. Diglosia juga ditemukan pada masyarakat yang menggunakan lebih dari dua bahasa. Lebih lanjut dikatakan pula bahwa ketetapan pemilihan variasi bahasa dalam hubungan sosial banyak ditentukan oleh kesadaran penutur terhadap kapan dan di mana tuturan itu diungkapkan. Topik percakapan merupakan satu rangkaian dengan tempat bicara dan waktu bicara.

Chaer dan Leoni (2004: 85) mengatakan bahwa bilingualsme kemampuan seorang penutur untuk menggunakan dua bahasa dengan sama baiknya. Sedangkan multilingualisme atau keanekabahasaan yaitu keadaan digunakannya lebih dari dua bahasa oleh seseorang dalam pergaulannya dengan orang lain secara bergantian. Sejatinya bilingualisme dan multilingualisme memiliki persamaan.

Kridaklaksana (dalam Mustikawati, 2015:54) mengatakan bahwa campur kode adalah penggunaan bahasa dari satu bahasa ke bahasa lain untuk memperluas gaya bahasa atau ragam bahasa. Termasuk di dalamnya pemkaian kata, klausa, idiom, sapaan dan sebagainya. Suatu contoh ketika masuk dalam percampuran dalam suatu komunikasi yang dikembangkan oleh suatu penutur bilingual atau multilingual. Ia menggunakan unsur bahasa $\mathrm{X}$ yang digunakan dalam tuturan bahasa $\mathrm{Y}$. Maka hal tersebut akan menjadi sebuah peristiwa campur kode.

Santri ialah sebutan untuk orang-orang yang sedang mengaji atau nyantri di pondok pesantren. Dunia pesantren tidak akan pernah luput dari yang namanya kyai, santri, dan tradisi. Pesantren pasti ada yang namnya santri. Santri inilah yang mulai membentuk tradisi-tradisi pesantren termasuk bahasa menciptakan berbagai macam bahasa di dalamnya. Kata pesantren berasal dari kata santri yang berawalan "pe" dan akhiran "an" yang dikarenakan pengucapan kata itu kemudian diubah menjadi "en" (pesantren). Yakni sebutan untuk bangunan fisik atau asrama di mana para santri bertempat. Tempat itu dalam bahasa jawa dikatakan pondok atau pemondokan. Adapun kata santri sendiri berasal dari kata cantik, yang berarti murid dari seorang resi yang juga biasa menetap dalam satu tempat yang dinamakan padepokan. Pesantren mempunyai persamaan dengan padepokan dalam beberapa hal yakni murid (cantik dan santri), adanya guru (kyai dan resi), adanya bangunan (pondok dan padepokan), dan adanya kegiatan belajar mengajar yang dikemukakan oleh Fuad (dalam Muhakamurrohmah, 2014).

Pesantren merupakan pendidikan tertua di Indonesia. pesantren telah mampu melahirkan para ulama besar yang ikut serta mengatur keutuhan negara. Hal itu karena pesantren merupakan tempat dakwah candardimuka bagi para santri sebelum benar-benar terjun ke masyarakat. Pondok pesantren pula sebagai tempat menimba ilmu para santri yang mengfokuskan pada keilmuan agama. Kata pesantren tidak akan jauh dari yang namanya keanekaragaman. Mulai dari budaya yang bermacam-macam, tradisi yang berbeda, santri yang berbeda hingga bahasa keseharian yang mereka gunakan tentu akan berbeda dari daerah satu dengan daerah lain (Muhakamurrohmah, 2014).

Dilihat dari budaya yang ada di pesantren, para santri tentu akan datang dari berbagai daerah untuk belajar di pondok pesantren. Hal ini yang perlahan memunculkan suatu kebudayaan baru, dapat berupa multilingual, atau penggunaan banyak bahasa di dalam pondok pesantren. Oleh sebab itu, para santri tidak hanya menggunakan satu bahasa daerah mereka, namun juga ikut serta dalam meneysuaikan bahasa teman-teman sebayanya. Penggunaan bahasa yang lebih dari satu maka penyebutan masyarakat tersebut ialah masyarakat multilingual. Oleh karena itu adanya campur kode yang terjadi dapat dilakukan untuk menyesuaikan situasi yang berlangsung. Tetapi bukan mencampurkan kode-kode tersebut. Wardaught (dalam Murni, 2012:67) mengemukakakan bahwa masyarakat multilingual terjadi akibat banyaknya imigran, pengunjung, atau anak-anak hasil dari perkawinan campuran. 
Tidak hanya pada lingkup masyarakat, di dalam pondok pesantren sendiri akan banyak ditemukan keanekaragaman berbahasa yang dituturkan para santri. Meskipun, sejatinya mereka hidup dalam satu tempat, namun multilingual telah muncul sejak lama di pesantren. Suatu pesantren dapat diamati dari tradisi yang mereka tanamkan. Masyarakatpun seperti itu, dapat diamati dari bahasa sehari-hari yang mereka gunakan. Kekhasan, tradisi maupun budaya yang ada dilingkup masyarakat dapat dilihat dari penyampaian bahasa yang ada pada budaya tersebut. Variasi bahasa dan tatanan sosial berjalan paralel atau beriringan pada arah yang sama dan urutan yang sama. Penalosa (dalam Giyoto, 2013) menyatakan bahwa sosiolinguistik juga muncul karena gagasan bahwa fenomena sosial dan linguistik berada pada tingkat yang sama. Sehingga data yag sama dapat digunakan untuk menganalisis baik bentuk bahasa maupun kategori-kategori sosialnya.

Penelitian ini mengarah pada penggunaaan bahasa multilingual yang terjadi di suatu komunitas santri pondok pesantren Mahasiswa Darussalam di Kartasura. Hal ini sangat menarik diteliti karena suatu komunitas kecil yang komunikasinya menggunakan tidak hanya satu bahasa. Asumsi yang sama dikemukakan oleh Bell (dalam Murni, 2012) bahwa bahasa tidak pernah monolitik, keberadaannya serta hal yang wajar karena tidak ada negara yang monolingual. Sedangkan dalam penelitian ini mengfokuskan pada tuturan sehari-hari para santri di pondok pesantren yang mayoritas para santrinya datang dari berbagai daerah. Misalnya Kebumen dengan bahasa ngapak, Sumedang dengan bahasa sunda, Surakarta sendiri yang cenderung logatnya lebih halus, Jawa Timuran yang cenderung lebih kasar dan bahasa-bahasa daerah lainnya yang lebih menarik.

Penelitian ini telah dilakukan sebelumnya oleh Dewi Murni (2012) pada laporan hasil penelitiannya yang berjudul Penggunaan Bahasa oleh Masyarakat Multilingual di Kelurahan Senggarang Provinsi Kepulauan Riau. Hanya saja penelitiannya difokuskan pada suatu analisis bahasa dari daerah-daerah di Riau yang yang masyarakatnya banyak menggunakan bahasa dari daerahnya masing-masing. Sedangkan penelitian ini berfokus pada pondok pesantren yang di dalamnya terdapat komunitas santri dengan penggunaan bahasa yang bervariasi atau multilingual dalam percakapan sehari-hari.

Selain penelitian yang dilakukan oleh Dewi Murni, penelitian lain juga dilakukan oleh Ni Luh Ayu Gayatri tentang Alih Kode dan Campur Kode Guru dalam Pembelajaran Bahasa Indonesia Kelas VII SMP N 4 Kubutambah. Penelitian ini dalakukan pada tahun (2016). Mahasiswa jurusan Bahasa dan Satra Indonesia Universitas Pendidikan Ganesha Singaraja, Indonesia. penelitian ini mengani campur kode, dan alih kode yang dilakukan guru pada saat pembelajaran bahasa Indonesia di sekolah Menengah pertama.

Penggunaan bahasa pondok pesantren yang lebih dari satu ini menarik untuk diamati dan diteliti. Secara keseluruhan penelitian ini mengarah pada bermacam-macam keanekaragaman bahasa yang digunakan di dalam pondok pesantren Mahasiswa Darussalam tersebut. Penggunaan bahasa yang beranekaragam seperti, alih kode dan campur kode juga ikut serta diamati dalam penelitian ini. Melihat faktor-faktor dan terjadi antar penutur satu dengan penutur lain. selain itu untuk mengetahui fungsi dari kedua belah pihak penutur apabila menggunakan campur kode dan alih kode. Tujuan dari penelitian ini ialah untuk melihat kebenaran data dan membuktikan kaebsahan data yang diteliti. Bahwa, di dalam sebuah pondok pesantren lebih banyak dan sering menggunakan multilingal atau keanekaragamn bahasa. Oleh sebab itu tujuan utama dari penelitain ini ialah mengidentifikasi wujud bahasa multilingual dan faktor-faktor yang menjadi penyebab adanya bahasa multilingual.

\section{METODE}

Metode dalam penelitian ini ialah deskriptif kualitatif. Menurut Denzin dan Lincoln (dalam Lexy 2011: 5) mengatakan bahwa penelitian kualitatif adalah penelitian yang menggunakan latar alamiah, dengan maksud menafsirkan fenomena yang terjadi dan dilakukan dengan jalan melibatkan berbagai metode yang ada. Sumber data yang diambil dari penelitian ini yaitu peristiwa tutur yang diucapkan 
santri dalam percakapan sehari-hari di pondok pesantren Mahasiswa Darussalam di Kartasura. Teknik pengumpulan data yang akan diteliti melalui observasi dan wawancara dalam tuturan yang terjadi sehari-hari oleh para santri yang kemudian direkam dan dicatat sebagai data penelitian. Tempat penelitain ini dilaukan di pondok pesantren Mahasiswa Darussalam yang berada di Kartasura. Peneliti secara langsung terjun ke pondok tersebut untuk mengamati tuturan para santri. Waktu penelitain dilakukan pada Desember 2018.

\section{HASIL PENELITIAN DAN PEMBAHASAN}

\section{Wujud Bahasa Multilingual}

Wujud bahasa multilingual dalam temuan data dapat dilihat dari dua sisi yaitu wujud bahasa yang berupa alih kode dan campur kode. Dalam konteks 1 terlihat wujud bahasa alih kode dan pada konteks 2 terlihat adanya wujud bahasa campur kode.

\section{Konteks 1}

Percakapan antara Aulia dan Dian. Dian merupakan salah satu santri yang berasal dari Subang Jawa Barat yang masih sering menggunakan bahasa Sunda.

Dian(1) :Aul, kumaha atuh jadinya?, tetehku ayeuna nanya". 'Aul bagaimana jadinya? Kakakku sekarang tanya'

Aulia(2) : "I don't know miss, coba takokke neng $\boldsymbol{m b}$ Nisa" 'Saya tidak tahu mbak, coba tanyakan ke mbak Nisa'

$\operatorname{Dian}(3) \quad$ : "Iih.. Mb Nisa Aina? Abdi mah gak tahu" "Iih.. Mbak Nisa di mana? Saya tidak tahu"

Aulia(4) : "Ya apalagi ana? Nyong ora weruh sedino mbok".

'Ya apalagi Saya? Saya tidak lihat seharian tuh'.

Tuturan (1) dan (2) merupakan penggunaan alih kode yaitu dari bahasa Sunda ke bahasa Inggris. Hal ini terbukti pada kalimat kumaha atuh, jadinya? Tetehku ayeuna nanya. Jawaban yang dituturkan oleh Aulia yaitu beralih menggunakan dua bahasa, yaitu bahasa Inggris pada kalimat $\boldsymbol{I}$ don't know miss dan bahasa Jawa pada kalimat takokke neng mb Nisa. Selain itu, pada tuturan ke (3) beralih ke bahasa Arab yaitu pada kata Aina yang dituturkan Dian kepada Aulia. Sedangkan pada tuturan ke (4) Aulia menjawab dengan peralihan bahasa Jawa ngapak dengan kalimat Nyong ora weruh sedino mbok.

Pada percakapan di atas, menunjukkan banyaknya peralihan bahasa yang dituturkan para santri. Peralihan bahasa yang digunakan dalam satu percakapan antar Santri di atas terlihat beralih empat bahasa yaitu bahasa Indonesia, Jawa ngapak, Inggris, dan Sunda. Berbagai macam bahasa yang digunakan menunjukkan bahwa di dalam Pondok Pesantren Mahasiswa Darussalam banyak adanya multilingual.

\section{Konteks 2}

Percakapan ini terjadi antara Nina seorang Santri asal Jakarta dengan Putri, Santri asal Solo. Nina(5) : 'Eh tahun kemarin di pondok $\boldsymbol{k i}$ ada acara kilatan, ada program bahasa Arab dan Inggris, masak iya tahun ini gak ada?'

'Eh tahun kemarin di pondok ini ada acara kilatan, ada program bahasa Arab dan Inggris, masak iya tahun ini tidak ada?'

\section{Putri(6) : 'Ora reti aku yen iku'}

'Tidak tahu aku kalau masalah itu' 
Nina(7) : 'Lha koe kan pengurusnya? Masak gak tahu sih?'

'Lha kan kamu pengurusnya? Masak tidak tahu sih?'

Putri(8) : 'Jare sopo? opo yo yen pengurus iku kudu reti kabeh? kan enggak mesti to?'

'Kata siapa? Apa iya kalau pengurus itu harus tahu semua? Tidak harus kan?'

Unsur-unsur yang terlibat dalam campur kode apabila dilihat dalam peristiwa tutur para Santri sehari-hari jika dilihat dari segi unsur bahasanya maka akan ada campur kode mulai dari kata, frasa, klausa, maupun kalimat. Wujud campur kode yang terjadi pada tuturan (5) di atas berupa campur kode kata yang dituturkan oleh Nina berupa kata $\boldsymbol{k i}$, yang dalam bahasa Indonesia memiliki arti ini. Tuturan (6) terdapat juga campur kode berupa kalimat pada tuturan yang dituturkan oleh Putri dengan kalimat ora reti aku yen iku yang berarti dia tidak tahu mengenai hal apa yang di bicarakan. Tuturan (7) terjadi campur kode pada kata koe yang berarti kamu. Tuturan (8) dan dengan kalimat jare sopo? yang berarti kata siapa?, opo yo yen pengurus iku kudu reti kabeh yang berarti tidak semua pengurus itu harus mengerti semua hal, mesti to? yang memiliki arti seharusnya.

\section{Konteks 3}

Percakapan berlangsung ketika salah seorang santri menyuruh piket santri lain, santri yang terlibat ialah Widya Asal Jakarta dan Diah asal Madura

Widya (9) : 'Diah, kotor banget gak dibersihin, hari ini hedeh piket kan?'

'Diah, Kotor sekali tidak dibersihkan, hari ini kamu piket kan?'

Diah (10) : 'Iyot' 'Iya'

Widya (11) : 'Hedeh lakoh apah? Bisa piket sekarang gak? Udah siang nih'

'Kamu lagi apa? Bisa piket sekarang tidak? Sudah siang ini'

Diah (12) : 'Engko gik ngakan'

'saya lagi makan'

Widya (13) : 'Ngakan meloloh, Dulieeeen Diaaah...!!!'

'Makan terus, cepat diah'

Bentuk campur kode yang terjadi pada tuturan (9) di atas berupa campur kode bahasa Jakarta dan Madura. Kalimat yang dituturkan oleh Widya berupa kalimat Bahasa Indonesia yang tidak baku dan diucapkan dengan logat anak kota. Kemudian tuturan hedeh dalam bahasa Madura memiliki arti kamu. Tuturan (10) merupakan bahasa Madura iyot yang berarti iya yang dituturkan oleh Diah. Terdapat juga campur kode antara bahasa Madura dan Jakarta pada data nomor (11) yang berupa kalimat pada tuturan yang dituturkan oleh Widya hedeh lakoh apah? Bisa piket sekarang gak? Udah siang nih yang berarti kamu sedang apa? Bisa piket sekarang tidak? Sudah siang ini. Tuturan (12) terjadi campur kode pada kata engko gik ngakan yang berarti saya sedang makan. Tuturan (13) dan dengan kalimat ngakan meloloh, yang berarti makan terus, dan Dulien yang berarti cepat atau memiliki makna harus sekarang.

Berdasarkan data di atas, telah menunjukkan bahwa penggunaan lebih dari satu bahasa terjadi di pondok pesantren Mahasiswa Darussalam yaitu bahasa Jakarta dan Madura. Banyaknya bahasa yang digunakan akan memudahkan para santri yang belum bisa bahasa daerah di pondok, selain itu hal tersebut dapat memperluas pengetahuan kebahasaan dari teman sebaya di pesantren.

\section{Konteks 4}

Percakapan antara Umamah yang berasal dari Solo dan Ayu yang berasal dari Jawa Timur yang menggunakan bahasa Jawa sebagai wujud pergantian alih kode.

Umamah (14) : 'Ayu, kon meh tuku mangan ra?' 


\author{
'Ayu, kamu mau beli makan tidak?' \\ Ayu (15) \\ : 'Ora mbak, aku wes nitip cah-cah' \\ 'Tidak mbak, saya sudah nitip anak-anak' \\ Umamah (16) : 'Oh Tak kiro, yowes' \\ 'Oh kukira, ya sudah'
}

Tuturan di atas merupakan peralihan antara bahasa Malang Jawa Timur dan bahasa Solo Jawa Tengah. Data (14) yang dituturkan oleh Umamah Ayu, kon meh tuku mangan ra? yang memiliki arti Ayu, kamu mau beli makan tidak?. Kon dalam versi bahasa Malang adalah kamu. Kemudian pada Data (15) Ora mbak, aku wes nitip cah-cah yang dimaknai Tidak mbak, aku sudah titip anak-anak, cah-cah menurut secara bahasa Jawa, khusunya Jawa Tengah dimaksudkan dengan kata lain anakanak. Setelah itu, Umamah pada data (16) Oh Tak kiro, yowes yang artinya oh ya sudah.

Percakapan di atas membuktikan bahwa santri Darussalam berasal dari berbagai kalangan dan daerah sehingga bahasa keseharian yang digunakan begitu beragam. Keunikan di sini ialah para santri mampu memahami dan berinteksi secara lancar meski menggunakan bahasa yang beragam.

Campur kode adalah pemakaian dua bahasa atau lebih dengan saling memasukan unsur yang satu ke unsur yang lain secara konsisten. Percakapan yang terjadi di atas telah mengamai campur kode antar penutur. Campur kode yang sering terjadi antara Santri dengan Santri lainnya menggunakan campur kode bahasa Jawa dan bahasa Indonesia. campur kode terjadi karena suatu kebiasaan, adapun faktor yang melatarbelakangi terjadinya campur kode ialah faktor kebahasaan, dan faktor sikap. Campur kode dapat dikatakan sebagai bagian dari satu variasi bahasa tertentu yang digunakan penutur secara sadar dan mendasar dengan menggunakan unsur-unsur bahasa lain yang dilakukan sebagai strategi komunikasi serta dalam rangka menjelaskan atau menerjemahkan. Wujud campur kode yang ditemukan dalam percakapan di atas melibatkan unsur-unsur bahasa Jawa dan bahasa Indonesia dalam penyisipan yang lebih dominan pada bahasa Jawa.

\title{
Faktor Penyebab Terjadinya Peristiwa Alih Kode dan Campur Kode Pembicara atau Penutur
}

Seorang pembicara atau penutur seringkali melakukan alih kode dan campur kode untuk mendapatkan keuntungan dan manfaat dari apa yang telah dituturkan. Alih kode daan campur kode biasanya dilakukan oleh penutur yang sadar. Pembicara atau penutur di atas dilakukan oleh Dian dan Nina.

\section{Pendengar atau lawan tutur}

Lawan bicara atau lawan tutur juga dijadikan sebagai sebab adanya alih kode dan campur kode, karena setiap lawan tutur tentu memiliki ragam bahasa yang bervariasi. Dalam hal ini biasanya kemampuan bertutur pada lawan tutur berlatarbelakang sama bahasanya dengan penutur. Pendengar atau lawan tutur di atas dilakukan oleh Aulia dan Putri.

\section{Perubahan situasi dengan adanya orang ketiga}

Kehadiran orang ketiga atau orang lain yang tidak memiliki latar belakang bahasa yang sama dengan bahasa yang sedang dituturkan menjadi penyebab terjadinya alih kode. Hadirnya orang ketiga dapat menentukan perubahan pada bahasa dan varian yang akan digunakan.

\section{Perubahan dari formal ke informal}

Peruahan situasi dalam pembicaraan dapat menyebabkan alih kode. Peralihan dari situasi formal ke informal mengakibatkan beralih pula bahasa atau ragam bahasa yang digunakan. Misalnya dalam pondok terdapat dua santri yang berbincang menggunakan ragam santai, kemudian datanglah seorang ustadz sehingga perbincangan yang digunakan harus menggunakan bahasa formal. 


\section{Perubahan topik pembicaraan}

Berubahnya topik pembicaraan dapat mengakibatkan terjadinya alih kode dan campur kode. Perubahan topik pembicaraan dilakukan untuk merubah topik pembicaraan yang dilakukan oleh penutur ke mitra tutur dengan tujuan agar pihak orang ketiga tidak mengetahui topik pembicaraan yang dibicarakan oleh penutur dan mitra tutur sebelumnya.

\section{SIMPULAN}

Pemakaian bahasa dalam masyarakat berdwibahasa atau bermultibahasa merupakan fenomena yang menarik untuk dikaji dari perspektif sosiolinguistik. Masyarakat Indonesia sebagian besar adalah masyarakat yang berdwibahasa. Adanya kedwibahasaan atau kemultibahasaan tersebut dapat memunculkan pemakaian bahasa yang bervariasi dalam masyarakat. Berdasarkan paparan di atas, mengenai pemakaian bahasa di Pondok Pesantren Mahasiswa Darussalam yang memiliki kekhasan dalam bahasa dan ranah kehidupan sehari-hari mempunyai kekhasan yang berupa campur kode dan alih kode. Oleh sebab itu terjadinya keanekaragaman bahasa yang terjadi membuktikan bahwa di pondok begitu banyak Santri yang menggunakan Multilingual. Sebab di manapun tempatnya tidak ada yang hanya menggunakan satu bahasa, melinkan pasti menggunakan banyak bahasa.

\section{DAFTAR PUSTAKA}

Chaer, A., Agustina, L. 2004. Sosiolinguistik Perkenalan Awal. Jakarta: PT Rineka Cipta.

Giyoto. 2013. Pengantar Sosiolinguistik. Sukoharjo: Fataba Press.

Indriani, S. M., Nyoman S., Ni L. A. G. 2016. "Alih Kode dan Campur Kode dalam Pembelajaran Bahasa Indonesia Kelas VII SMP Negeri 4 Kubutambahan”. e-Juornal JPBSI Universitas Pendidikan Ganesha. 4 (2), 56-66.

Jendra, Made Iwan Indrawan. 2010. Sociolinguitics The Study of Societies' Languanges. Yogyakarta: Graha Ilmu.

Marni, Wa Ode. 2016. "Campur Kode dan Alih Kode dalam Peristiwa Jual Beli di Pasar Labuan Tobelo Kecamatan Wakorumba Utara Kabupaten Buton Utara”. Jurnal Bastra. 2 (1), 89-100.

M. Muhammad. 2016. "Musnah Bahasa Daerah Akibat Bilingual dan Multilingual (Studi Kasus Bahasa "Tana" di Kota Ambon". Jurnal Fikratuna. 8 (2), 16-28.

Moleong, J Lexy. 2012. Metodologi Penelitian Kualitatif. Bandung: PT Remaja Rosdakarya.

Muhakamurrohmah, Ahmad. 2015. "Pesantren: Santri, Kiai dan Tradisi”. Jurnal IBDA'. 12 (2), 4557.

Murni, Dewi Riauwati. 2012. Penggunaan Bahasa Oleh Masyarakat Multilingual di Kelurahan Senggaranag Provinsi Kepulauan Riau. Skripsi. Universitas Maritim Raja Ali Haji.

Mustikawati, Diyah Atiek. 2015. "Alih Kode Campur Kode Antara Penjual dan Pembeli (Analisis Pembelajaran Berbahasa Melalui Studi Sosiolinguistik". Jurnal Dimensi Pendidikan dan Pembelajaran. 3 (2), 35-47. 
Rahmawati, Siti Ruchaini. 2016. "Konseling Budaya Pesantren Studi Deskriptif Terhadap Pelayanan Bimbingan Konseling Bagi Santri Baru”. Jurnal Konseling Religi. 7 (1), 24-35.

Rokhman, Fathur. 2013. Sosiolinguistik Suatu Pendekatan Pembelajaran Bahasa dalam Masyarakat Multikultural. Yogyakarta: Graha Ilmu.

Sunahrowi. 2007. "Variasi dan Pengajaran Register Bahasa dalam Pengajaran Sosiolinguistik". Jurnal INSANIA. 12 (1), 23-34.

Tarigan, Henry Guntur. 2009. Pengajaran Kedwibahasaan. Bandung: Angkasa. 